\title{
NOWE GRANICE OBRONY KONIECZNEJ? UWAGI NA TLE NOWELIZACJI KODEKSU KARNEGO Z 8 GRUDNIA 2017 ROKU
}

\section{WSTĘP}

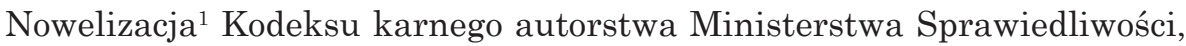
rozszerzająca w zamyśle autorów granice obrony koniecznej, została przyjęta przez Sejm 8 grudnia 2017 r. Punktem wyjścia prac resortu sprawiedliwości była konferencja prasowa ministra sprawiedliwości, na której zapowiedział on dokonanie stosownych zmian w Kodeksie karnym oraz złożenie kasacji na korzyść oskarżonych w przypadkach, które jego zdaniem nie uzasadniały skazania za przekroczenie granic obrony koniecznej osób broniących się przed napastnikiem ${ }^{2}$. Jednym z takich przypadków był kazus Zbigniewa T., w stosunku do którego minister sprawiedliwości - prokurator generalny postanowił złożyć kasację $e^{3}$ Paradoksalnie jednak w tym przypadku nie znalazłyby zastosowania nowe przepisy o obronie koniecznej, ze względu na ich ograniczenie do obrony na nieruchomości w myśl amerykańskiej zasady „mój dom - moja twierdza”. W związku z dokonana nowelizacją zasadne jest przedstawienie nowych zasad obrony koniecznej oraz określenia skutków dokonanej nowelizacji, przede wszystkim w zakresie, czy zmiana ta rzeczywiście poszerza granice obrony koniecznej.

\section{REGULACJA ART. 25 §A K.K.}

Nowela wprowadza do Kodeksu karnego nowy przepis pod postacią art. 25 $\S 2 \mathrm{a}$ k.k. w następującym brzmieniu: „Nie podlega karze, kto przekracza granice obrony koniecznej, odpierajac zamach polegajacy na wdarciu się do mieszkania, lokalu, domu albo na przylegający do nich ogrodzony teren lub odpierając zamach poprzedzony wdarciem się do tych miejsc, chyba że przekroczenie granic obrony koniecznej było rażące”.

\footnotetext{
${ }^{1}$ Ustawa z 8 grudnia 2017 r. o zmianie ustawy - Kodeks karny, Dz. U. 2018, poz. 20.

${ }^{2}$ Zob. <http://prawo.gazetaprawna.pl/artykuly/1038506,projekt-rozszerzenia-prawa-do-obrony- koniecznej.html> [dostęp: 6.01.2018].

${ }^{3}$ Zob. <https://wpolityce.pl/spoleczenstwo/338007-poszerzenie-obrony-koniecznej-w-praktycebedzie-kasacja-ws-niepelnosprawnego-ktory-ranil-nozem-napastnika> [dostęp: 6.01.2018].
} 


\section{Wyłączenie karalności}

Przekroczenie granic obrony koniecznej w myśl tego przepisu stanowić będzie okoliczność wyłączająca przestępność czynu, ponieważ prowadzi do dekompletacji struktury przestępstwa. W odniesieniu jednak do pięcioelementowej ${ }^{4}$ struktury przestępstwa wątpliwości pojawiają się co do tego, na którym etapie przestępstwa dochodzi do jego dekompletacji. Zarówno nowo wprowadzony przepis $\S 2 \mathrm{a}$, jak i przepis $\S 3^{5}$ art. $25 \mathrm{k} . \mathrm{k}$. stanowia, że sprawca „nie podlega karze”, co sugerowałoby wyłączenie karalności przestępstwa. Na gruncie jednak art. $25 \S 3$ k.k. Andrzej Zoll stwierdził, że przepis ten stanowi okoliczność wyłączającą winę, a nie karalność, ponieważ w chwili popełnienia czynu od sprawcy działającego w silnym wzburzeniu nie można było oczekiwać zachowania się zgodnego z regułami postępowania z dobrem prawnym ${ }^{6}$. Okoliczności jednak, o których mowa w przepisach $\S 2$ a i $§ 3$ art. 25 k.k., się różnią. W tym drugim przypadku w rzeczy samej sprawca nie jest w stanie w pełni rozpoznać ani pokierować swoim zachowaniem, co zbliża tę okoliczność do stanu niepoczytalności (art. 31 $\S 1$ k.k.). Wskazuje na to odwołanie się do stanu psychicznego defensora oraz poprzednie brzmienie tego przepisu ${ }^{7}$. W omawianym jednak przypadku przekroczenie granic obrony koniecznej nie jest skutkiem niemożności powstrzymania swojego działania w obliczu zamachu. Przemawia to zatem za postrzeganiem tej okoliczności jako podstawy wyłączenia karalności czynu, na co wskazuje także uzasadnienie projektu, w którym jest mowa o „uchy-

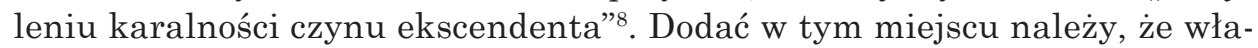
ściwe określenie podstawy wyłączenia przestępności czynu w jego strukturze ma zasadnicze znaczenie dla chociażby możliwości stosowania środków zabezpieczających czy też ewentualnej odpowiedzialności odszkodowawczej. Istotną także kwestią będzie zbieg podstaw wyłączenia przestępności na podstawie art. $25 \S 2 \mathrm{a}$ i $\S 3$ k.k. Możliwa jest bowiem sytuacja, w której odpierający zamach przekracza granice obrony koniecznej, działając pod wpływem usprawiedliwionego okolicznościami strachu, a jednocześnie do zamachu dochodzi na terenie jego nieruchomości. W takiej sytuacji, ze względów podanych powyżej, korzystniejsze dla odpierającego zamach będzie zastosowanie podstawy określonej w art. $25 \S 2 \mathrm{a}$ k.k. W tym jednak zakresie ustawa nie rozszerza granic obrony koniecznej, jak wielokrotnie tę kwestię

\footnotetext{
${ }^{4}$ W. Wróbel, A. Zoll, Polskie prawo karne. Czesść ogólna, Kraków 2013, s. 166.

${ }^{5} \mathrm{~W}$ brzmieniu nadanym ustawa z 5 listopada 2009 r. o zmianie ustawy - Kodeks karny, ustawy - Kodeks postępowania karnego, ustawy - Kodeks karny wykonawczy, ustawy - Kodeks karny skarbowy oraz niektórych innych ustaw, Dz. U. 2009, Nr 206, poz. 1589. W pierwotnej wersji Kodeksu karnego z 1997 r. przekroczenie granic obrony koniecznej spowodowane usprawiedliwionymi okolicznościami powodowało obligatoryjne odstapienie od wymierzenia kary, nie wyłączając jednak przestępności czynu.

${ }^{6}$ W. Wróbel, A. Zoll, op. cit., s. 361.

${ }^{7}$ Z. Jędrzejewski et al., w: System prawa karnego, t. 4: Nauka o przestepstwie. Wytaczenie i ograniczenie odpowiedzialności karnej, red. L. Paprzycki, Warszawa 2013, s. 229.

${ }^{8}$ Uzasadnienie projektu ustawy (druk nr 1871, Sejm VII kadencji), s. 1.
} 
przedstawiał resort sprawiedliwości ${ }^{9}$. Rozszerzenie granic obrony koniecznej nastapiłoby bowiem w razie odpowiedniej nowelizacji art. $25 \S 1$ k.k., czyli przepisu, który statuuje kontratyp obrony koniecznej. Omawiana nowelizacja zaś rozszerza jedynie wyłączenie przestępności czynu w razie przekroczenia jej granic. Czyn ten pozostaje czynem bezprawnym, ponieważ jego bezprawność w myśl art. $25 \S 1 \mathrm{k} . \mathrm{k}$. nie zostaje wyłączona, nie stanowi on jednak przestępstwa z powodu wyłączenia karalności ${ }^{10}$.

\section{Stan świadomości broniącego się}

Kolejnym istotnym zagadnieniem na gruncie nowego przepisu jest określenie jego zakresu stosowania. Zdaniem projektodawców niezbędne jest uzupełnienie dotychczasowego stanu prawnego o element przewagi działań obronnych nad atakiem ${ }^{11}$, co potwierdził Sąd Najwyższy, stwierdzając, że „przy dopuszczalności np. tylko równowagi pomiędzy tymi działaniami - zachodziłaby tylko społecznie niepożądana wzajemność, a nie skuteczna obrona" ${ }^{12}$. W tym także duchu wypowiadają się przedstawiciele części doktryny, którzy wskazuja, że w społecznej ocenie dotychczasowy kształt obrony koniecznej faworyzował dobro napastnika ${ }^{13}$. Z drugiej jednak strony na tym tle uwidacznia się także nieznajomość prawa wśród członków społeczeństwa - częste jest bowiem przekonanie, że tak jak jest to ukazywane w amerykańskich filmach, broniący się ma prawo do nieograniczonej reakcji ${ }^{14}$, w czym też można upatrywać takiej, a nie innej oceny funkcjonowania tego kontratypu.

Nie wchodząc w szczegóły, ze względu na tożsamość pojęcia obecnego w dotychczasowym stanie prawnym, stwierdzić trzeba, że przekroczenie granic obrony koniecznej może nastapić w dwóch formach - ekscesu intensywnego, polegającego na zastosowaniu sposobu obrony niewspółmiernego do płynącego z zamachu niebezpieczeństwa, oraz ekscesu ekstensywnego, polegającego na przedsięwzięciu czynności obrończych przedwcześnie lub za późno ${ }^{15}$. Prawnym ograniczaniem obrony koniecznej jest jej współmiernośćc ${ }^{16}$, która przedstawiana w orzecznictwie jest w dwójnasób - zakładając możliwość stosowania

${ }_{9}$ Zob. np. oficjalny komunikat na stronie internetowej Ministerstwa Sprawiedliwości: <https://ms.gov.pl/pl/informacje/news, 9312,rozszerzenie-prawa-do-obrony-koniecznej.html> [dostęp: 6.01.2018].

${ }^{10}$ Zob. <http://prawo.gazetaprawna.pl/artykuly/1098528,obrona-konieczna-po-nowemu.html> [dostęp: 6.01.2018].

${ }^{11}$ Uzasadnienie projektu ustawy, s. 1.

${ }^{12}$ Wyrok SN z 10 stycznia 1969 r., IV KR 234/68, Lex nr 20793.

${ }_{13}$ T. Tabaszewski, Eksces intensywny obrony koniecznej w orzecznictwie, „Prokuratura i Prawo” 2010, nr 12, s. 71; zob. także M. Szafraniec Przekroczenie granic obrony koniecznej w polskim prawie karnym, Kraków 2004, s. 77.

${ }^{14}$ P. Bachmat, Instytucja obrony koniecznej $w$ praktyce prokuratorskiej $i$ sqdowej, Warszawa 2003, s. 10.

${ }^{15}$ J. Giezek, w: M. Bojarski (red.), Prawo karne materialne. Część ogólna i szczególna, Warszawa 2017 , s. $172-173$.

${ }^{16}$ Wprowadzona dopiero w regulacji obrony koniecznej w Kodeksie w 1969 r. - zob. M. Maśnicka, Wptyw ideologii ZSRR na ksztatt instytucji obrony koniecznej $w$ Polsce $i w$ Niemczech, „Polski Rocznik Praw Człowieka i Prawa Humanitarnego” 2011, nr 2, s. 319-320. 
wszelkich skutecznych metod odparcia zamachu lub, co stanowi przeważajace stanowisko, użycia najłagodniejszego sposobu spośród skutecznych ${ }^{17}$. Jak zauważa Andrzej Marek, eksces stanowi czyn podjęty w związku z zaistnieniem przesłanek obrony koniecznej, a więc w związku z bezprawnym i bezpośrednim zamachem na dobro chronione prawem, ale z przekroczeniem współmierności tej obrony ${ }^{18}$. Autor ten zwraca także uwagę na to, że oprócz obiektywnych warunków obrony koniecznej niezbędne jest także ustalenie warunków subiektywnych (podmiotowych) wskazujących na zawinienie przekraczania tych granic ${ }^{19}$. Dokonywanie oceny współmierności zastosowanego środka przez odpierającego atak powinno następować każdorazowo z perspektywy ex ante, czyli oceny dokonywanej przez obiektywnego obserwatora w chwili podejmowania działań obronnych ${ }^{20}$.

Nowy przepis stanowi, że nie jest karalne przekroczenie granic obrony w przypadku zamachu polegającego na „wdarciu się do mieszkania, lokalu, domu albo na przylegajacy do nich ogrodzony teren lub odpierajac zamach poprzedzony wdarciem się do tych miejsc". Okolicznością uzasadniająca zatem wyłączenie karalności w tym przypadku nie będzie ani sposób działania odpierającego zamach, ani stan jego świadomości, lecz sam przedmiot zamachu, co wyraża projektodawca w uzasadnieniu, stanowiąc, że „projektowana zmiana przesuwa akcent ze sfery emocjonalnej osoby odpierajaccej zamach na majacy charakter zobiektywizowany przedmiot zamachu"21. Wystarczajace jest jedynie, aby broniący się miał świadomość tego, że odpiera on bezprawny zamach na dobro chronione prawem ${ }^{22}$. Co do zasady bez znaczenia przy tym pozostaje sposób działania odpierającego zamach. Niemniej jednak jego motywacja musi odpowiadać woli obrony danego dobra prawnego i w tym zakresie pozostaje aktualne stanowisko wypracowane przez orzecznictwo, wedle którego konieczne jest ustalenie, że defensor, działając w ramach ekscesu, obejmował swoją świadomością i wolą naruszenie dóbr napastnika w zakresie dalszym, aniżeli wynikajacym z zamachu ${ }^{23}$. Wobec tego słusznie A. Marek twierdzi, że nie można uznać za przekroczenie granic obrony koniecznej nieumyślne spowodowanie śmierci włamywacza usiłujacego się wedrzeć do domu, w sytuacji gdy broniący się nie przewidywał ani nie godził się, że jego działanie może spowodować śmierć napastnika ${ }^{24}$. Rolą tego wymogu jest odróżnienie rzeczywistych działań obronnych od społecznie nagannych aktów odwetu, wendety, zemsty itp. ${ }^{25}$

17 T. Tabaszewski, op. cit., s. 72; zob. też: A. Marek, Obrona konieczna w prawie karnym. Teoria i orzecznictwo, Warszawa 2008, s. 115-116; M. Mozgawa Obrona konieczna w polskim prawie karnym (zagadnienia podstawowe), „Annales Universitatis Mariae Curie-Skłodowska Lublin Polonia. Sectio G” 2, 2013, s. 174.

18 A. Marek, op. cit., s. 119.

19 Ibidem, s. 123.

20 T. Tabaszewski, op. cit., s. 72-73.

21 Uzasadnienie projektu, s. 3.

22 J. Giezek, op. cit., s. 169.

23 A. Marek, op. cit., s. 123-124.

${ }_{24}$ Za: R. Góral, Obrona konieczna w praktyce, Warszawa 2011, s. 82.

25 A. Marek, op. cit., s. 124. 
Omawiana jednak regulacja pozostaje odrębną od art. $25 \S 3$ k.k. podstawą do wyłączenia przestępności czynu, co pozwala na przyjęcie szerszej od dotychczasowej możliwości wyłączenia przestępności czynu broniącego się. Po pierwsze, odpierający zamach nie musi czuć się w ogóle zagrożony ze strony sprawcy przestępstwa. Na gruncie tego przepisu dopuszczalne będzie podjęcie takich czynności, które w dotychczasowym stanie prawnym bez wątpienia kwalifikowane były jako przekroczenie granic obrony koniecznej skutkujące jedynie fakultatywną możliwością zastosowania nadzwyczajnego złagodzenia kary lub odstapienia od jej wymierzenia (art. $25 \S 2$ k.k.). Swoistym wentylem bezpieczeństwa przed nadużywaniem art. $25 \S 2 \mathrm{a} \mathrm{k} . \mathrm{k}$. jest określone in fine tego przepisu sformułowanie: „chyba że przekroczenie granic obrony koniecznej było rażące”. Jak wynika z uzasadnienia projektu, dotyczyć to ma sytuacji, w której „sposób obrony czy też użyte w tym celu środki byłyby oczywiście niewspółmierne do zagrożenia wynikającego z zachowania napastnika" ${ }^{26}$. W takiej sytuacji według projektodawcy „ekscendent może skorzystać z instytucji niepodlegania karze przewidzianej w art. $25 \S 3 \mathrm{k} . \mathrm{k}$., to jest wtedy, gdy rażące przekroczenie granic nastapiło pod wpływem strachu lub wzburzenia usprawiedliwionego okolicznościami [a w przypadku niemożliwości jej zastosowania ze względu na brak przesłanek - przyp. J.K.] sąd może zastosować przewidziane nadzwyczajne złagodzenie kary, a nawet odstapić od jej wymierzenia"27.

W dotychczasowej jednak literaturze prawa karnego podkreśla się, że przekroczenia granic obrony koniecznej możliwe jest tylko wtedy, gdy w ogóle zaistnieje stan uzasadniajacy taką obronę, do czego z kolei konieczny jest brak rażącej dysproporcji miedzy wartością dobra zaatakowanego przez napastnika a wartością dobra poświęconego przez odpierającego zamach ${ }^{28}$. Wynikałoby więc z tego, że wbrew tezie zawartej w uzasadnieniu projektu ustawy, rażące działanie odpierającego zamach skutkowałoby jego odpowiedzialnością karna. Trzeba dokonać jednak rozróżnienia dwóch płaszczyzn, o których mowa powyżej. Istota obrony koniecznej jest bowiem brak rażącej dysproporcji, ale między dobrami prawnymi (atakowanym oraz poświęconym). W tym zakresie nowelizacja wprowadzajacca przepis art. $25 \S 2 \mathrm{a}$ k.k. niczego nie zmienia. Działanie odpierajacego zamach odpowiadające podawanemu często przykładowemu kazusowi, w którym właściciel sadu zastrzeli z broni palnej chłopca kradnącego z drzewa jabłko ${ }^{29}$, mimo że czyn stanowi odparcie zamachu związanego z nieruchomościa, będzie w pełni czynem karalnym i nie znajdzie do niego zastosowanie nawet możliwość nadzwyczajnego złagodzenia kary. Rażące przekroczenie granic obrony koniecznej, o którym mowa w art. 25 § 2 a in fine k.k., dotyczyć będzie takich sytuacji, w których obrona konieczna sama w sobie była uzasadniona, a więc brak jest dysproporcji między dobrem prawnym chronionym a poświęconym, a rażące jest jedynie samo działanie sprawcy.

Pewne wątpliwości można podnieść na gruncie kradzieży mienia o wartości $^{30}$ kwalifikującego go jako wykroczenie (art. 119 § 1 k.w.). W pierwszej kolej-

${ }^{26}$ Uzasadnienie projektu, s. 1.

27 Ibidem, s. 3.

28 W. Wróbel, A. Zoll, op. cit., s. 358-359.

${ }^{29}$ Ibidem, s. 359.

${ }^{30}$ Od 1 stycznia 2018 r. granica przepołowienia wynosi 525 zł. Ministerstwo Sprawiedliwości przygotowało jednak projekt nowelizacji Kodeksu wykroczeń zakładający wprowadzenie stałej 
ności stwierdzić trzeba, że wdarcie się do mieszkania, o którym mowa w art. 25 $\S 2 \mathrm{a}$ k.k., nie musi oznaczać, że kradzież może być tylko dokonana z włamaniem, co wówczas wyłączałoby kwalifikowanie takiego czynu jako wykroczenia (art. 130 $\S 2$ k.w.). Wobec tego możliwe jest odpieranie czynu będącego wykroczeniem. Rodzi się zatem pytanie, czy w rozumieniu art. $25 \mathrm{k} . \mathrm{k}$. przez pojęcie zamachu należy rozumieć również zamach będący wykroczeniem. Z racji jednak określenia zamachu jako czynu bezprawnego stwierdzić trzeba, że obejmuje on zarówno czyny będace przestępstwami, jak i wykroczeniami.

\section{Miejsce bronienia się}

Najistotniejszą kwestią jednak na gruncie nowego przepisu art. 25 § 2a k.k. jest przedmiotowy zakres stosowania tego przepisu, który znajduje zastosowanie do odpierania zamachu polegającego „na wdarciu się do mieszkania, lokalu, domu albo przylegającego do nich ogrodzonego terenu lub odpierajac zamach poprzedzony wdarciem się do tych miejsc". Powyższy katalog ma charakter zamknięty, w szczególności nie jest dopuszczalne jego wykładnia w drodze analogii i jego rozszerzanie na inne miejsca zamknięte, np. samochód. Wynika to ze szczególnego charakteru gwarancyjnego norm prawa karnego i prymatu wykładni językowej ${ }^{31}$, która nakazuje ich wykładnię w kontekście językowym. Ponadto regulacja zawarta w tym przepisie ma charakter wyjątkowy, wobec czego również nie podlega wykładni rozszerzającej (exceptiones non sunt extendendae).

Krag zatem stosowania tego przepisu ograniczony został do czterech miejsc, którymi sa: mieszkanie, lokal, dom i przylegający do nich ograniczony teren. Na tym tle z pewnością powstaną spory interpretacyjne dotyczące tego, co należy rozumieć przez te pojęcia. Ich wykładnia jednak i wskazywanie desygnatów powinny odbywać się w zgodzie ze wskazaniami języka potocznego ${ }^{32}$. Słownik języka polskiego definiuje „mieszkanie” jako „pomieszczenie, lokal, w którym się mieszka, najczęściej na stałe; zwykle będące częścią jakiegoś budynku, składające się z pokoi, kuchni, łazienki, ubikacji i przedpokoju"33. Z kolei „lokal” według słownika to „część domu, pomieszczenie, mieszkanie”, natomiast „dom” to „budynek, budowla służąca jako miejsce zamieszkania, jako siedziba instytucji, sklepów, zakładów pracy itp.” albo „mieszkanie, pomieszczenia mieszkalne; lokal, w którym się mieszka" ${ }^{35}$. Przylegajacy z kolei do wskazanych miejsc ograniczony można zdefiniować opisowo jako część nieruchomości, działki zabudowanej domem, przeznaczony do użytkowania przez mieszkańców tego domu. Wskazane zatem definicje w mniejszym bądź więk-

\footnotetext{
granicy przepołowienia określonej kwotowo jako 400 zł. Projekt dostępny na stronie Rządowego Centrum Legislacji: <https://legislacja.rcl.gov.pl/docs//2/12299902/12442151/12442152/dokument295999.pdf> [dostęp: 6.01.2018].

${ }^{31}$ W. Wróbel, A. Zoll, op. cit., s. 117; zob. też: P. Wiatrowski, Dyrektywy wykładni prawa karnego materialnego w judykaturze Sadu Najwyższego, Warszawa 2013, s. 3 i n.

${ }^{32}$ L. Morawski, Wstep do prawoznawstwa, Toruń 2009, s. 134-136.

${ }_{33}$ Stownik wspótczesnego języka polskiego, red. B. Dunaj, Warszawa 1996, s. 518.

${ }^{34}$ Ibidem, s. 470.

${ }^{35}$ Ibidem, s. 185.
} 
szym stopniu dotyczą miejsc związanych z miejscem zamieszkiwania człowieka. Nie oznacza to jednak, że wskazane definicje wyczerpują w zupełności mogące się pojawić na tym tle wątpliwości.

Przede wszystkim trzeba zwrócić uwagę na stosunek, jaki zachodzi między wskazanymi terminami a zawartymi w innych gałęziach prawa definicjami legalnymi niektórych spośród tych pojęć. Przykładowo definicję mieszkania zawiera rozporządzenie Ministra Infrastruktury ${ }^{36}$, definicja lokalu występuje zarówno w ustawie o ochronie praw lokatorów ${ }^{37}$, jak i ustawie o własności lokali ${ }^{38}$. Wskazać jednak trzeba, że w szeregu przypadków prawo karne posługiwało się autonomiczną definicją niektórych terminów, niezależną od ich uregulowania w pozostałych gałęziach prawa ${ }^{39}$. Ratio legis tego przepisu uzasadnia, że również w tym przypadku należałoby dokonywać autonomicznej, niezależnej od cywilnej wykładni omawianych terminów. Na tym tle wskazać można także na przykładowe watpliwości, jakie prima facie moga powstać w praktyce stosowania omawianego przepisu. Pierwsza z nich dotyczy desygnatów określenia „ogrodzonego terenu”, o którym mowa w przepisie. To „ogrodzenie” oraz powiązane z nim „wtargnięcie sprawcy” wskazują na trwały element usadowiony na granicach działki odgraniczający ją od innych działek (np. płot, żywopłot, murek). Takie rozumienie powyższego terminu będzie $\mathrm{w}$ sposób istotny ograniczać jego stosowanie, albowiem skorzystanie z jego dobrodziejstwa w przypadku nieogrodzonego terenu będzie możliwe dopiero po wtargnięciu do znajdującego się na tym terenie domu.

\section{Forma zamachu}

Generalnie zamach uzasadniajacy zastosowanie obrony koniecznej stanowi zachowanie człowieka stwarzające bezpośrednie zagrożenie zniszczenia lub umniejszenia przydatności określonego dobra prawnego w odczuciu społecznym $^{40}$. Na tle art. $25 \S 2 \mathrm{a}$ k.k. zamach uzasadniajacy zastosowanie obrony może przybrać dwie formy - wdarcia się do pomieszczenia (lub przylegajacego terenu) jako samoistnego zamachu albo wdarcia się towarzyszącemu innemu następczemu czynowi. Zwraca uwage w tym miejscu określenie, którym posłużył się ustawodawca na opisanie zamachu sprawcy czynu zabronionego. Jego działanie bowiem ma polegać na „wdarciu się” na cudzy teren. Jak wynika z uzasadnienia projektu: „Szczególne okoliczności ataku, to jest wdarcie się do pomieszczeń mieszkalnych, a więc istotne naruszenie sfery prywatnej

$36 \S 3$ pkt 9 rozporządzenia Ministra Infrastruktury z 12 kwietnia 2002 r. w sprawie warunków technicznych, jakim powinny odpowiadać budynki i ich usytuowanie, t.jedn.: Dz. U. 2015, poz. 1422 .

37 Art. 2 pkt 4 ustawy z 21 czerwca 2001 r. o ochronie praw lokatorów, mieszkaniowym zasobie gminy i o zmianie Kodeksu cywilnego, t.jedn.: Dz. U. 2016, poz. 1610.

38 Art. 2 ust. 2 ustawy z 24 czerwca 1994 r. o własności lokali, t.jedn.: Dz. U. 2015, poz. 1892.

39 P. Ochman, Spór o pojęcie dokumentu w prawie karnym, „Prokuratura i Prawo” 2009, nr 1, s. 22; M. Gałązka, Rzecz w prawie karnym - pojęcie cywilnoprawne czy autonomiczne?, „Studia Prawnicze KUL” 2013, nr 1, s. 66.

40 Z. Jędrzejewski et al., op. cit., s. 175. 
jednostki i związane z tym w praktyce niebezpieczeństwo, powodują, że jest on na tyle społecznie szkodliwy, że jest usprawiedliwione podjęcie wszelkich środków mających na celu skuteczne powstrzymanie napastnika przed kontynuowaniem zamachu" ${ }^{41}$.

Zwraca zatem uwagę posłużenie się przez ustawodawcę znamieniem czasownikowym dla opisania czynności napastnika tożsamym z przedmiotem czynności wykonawczej przestępstwa zakłócenia miru domowego stypizowanego w art. 193 k.k. Zgodnie z tym przepisem, kto wdziera się do cudzego domu, mieszkania, lokalu, pomieszczenia albo ogrodzonego terenu, albo wbrew żądaniu osoby uprawnionej miejsca takiego nie opuszcza, podlega grzywnie, karze ograniczenia wolności albo pozbawienia wolności do roku. Jak pisze A. Zoll: „Przez »wdarcie się« należy rozumieć przełamanie, przy wkroczeniu do miejsc określonych w art. 193, nie tyle przeszkody fizycznej, lecz woli osoby uprawnionej. Wchodzą tu $\mathrm{w}$ grę wszelkie sposoby przedostania się do miejsca wymienionego $\mathrm{w}$ przepisie bez zgody chociażby domniemanej, a więc gwałtem, podstępem, pod fałszywym pozorem, groźbą" ${ }^{42}$. W orzecznictwie zwrócono także uwagę na to, że: „Warunkiem karalności za przestępstwo z art. 193 k.k. jest ogrodzenie terenu (posiadłości, działki) - parkanem, murem, płotem, itp., nie zaś rowem - gdyż to ogrodzenie wskazuje na to, że właściciel czy posiadacz nie życzy sobie wstępu osób trzecich” ${ }^{43}$. Wynika więc z tego, że pojęcie „wdzierania się" jest terminem szerszym aniżeli „włamanie”. Przedmiot ochrony jest bowiem skierowany w głównej mierze na wolność korzystającego z mieszkania, a nie na ochronę mienia ${ }^{44}$. Co więcej, sama odmowa opuszczenia lokalu wbrew żądaniu uprawnionej osoby stanowić będzie zamach w myśl art. $25 \mathrm{k} . \mathrm{k}$. popełniony w formie zaniechania ${ }^{45}$. Ze względu na potrzebę jednakowego wykładania tych samych znamion na gruncie tej samej ustawy powyższe uwagi znajdą zastosowanie także do pojęcia wdzierania się na gruncie art. 25 §a k.k.

\section{WPLYW NOWELIZACJI ART. 25 § 2 A K.K. NA WYBRANE TEZY ORZECZNICTWA}

Jak wskazuje Ministerstwo Sprawiedliwości w uzasadnieniu projektu ustawy: „Jedną z przyczyn nowelizacji jest ocena dotychczasowej praktyki stosowania prawa, która wskazuje na zbyt częste występowanie przypadków nieuzasadnionego pomijania przepisu art. $25 \S 1-3$ k.k. przy dokonywaniu prawnej oceny zachowania osoby, która w związku z odpieraniem bezprawnego zamachu naruszyła lub naraziła na niebezpieczeństwo dobra prawne napast-

\footnotetext{
${ }^{41}$ Uzasadnienie projektu, s. 3.

42 A. Zoll, w: idem (red.) Kodeks karny. Część szczególna, t. 2: Komentarz do art. 117-277 k.k., Warszawa 2013, komentarz do art. 193, teza nr 5.

${ }^{43}$ Postanowienie SN z 9 lipca 2013 r., III KK 73/13, Lex nr 1353965.

${ }^{44}$ J. Kosonoga, w: R. Stefański (red.), Kodeks karny. Komentarz, Warszawa 2015, s. 1160.

${ }^{45}$ Z. Jędrzejewski et al., op. cit., s. 176.
} 
nika”" oraz przekonanie, że „sądy zbyt rzadko stosują te kryteria współmierności sposobu obrony wypracowane przez Sąd Najwyższy, które gwarantuja efektywne korzystanie z kontratypu przewidzianego w art. 25 k.k.”47. Jak już jednak wspomniano we wstępie, przywołany przez Ministerstwo kazus Zbigniewa T. nie pozwala na zastosowanie w jego przypadku nowego przepisu, ponieważ odpieranie zamachu w tym przypadku nie miało związku z wdarciem się do mieszkania, lecz nastapiło na otwartym terenie. Podobnie rzecz przedstawia się w przypadku stanu faktycznego leżącego u podstaw orzeczenia Sądu Apelacyjnego w Katowicach, który uznał za przekroczenie granic obrony koniecznej działanie oskarżonej, uzasadniając to tym, że „oskarżona mogła skutecznie powstrzymać pokrzywdzonego używając mniej niebezpiecznego przedmiotu. Nawet używając noża mogła ugodzić nim w inna, mniej wrażliwa część ciała. Nie musiała wreszcie zadawać aż dwóch uderzeń"48, z tym jednak zastrzeżeniem, że brak było w okolicznościach tej sprawy wdarcia się do mieszkania, ponieważ pokrzywdzony był jego mieszkańcem, a zarzucany czyn miał związek z przemocą domową z jego strony.

W świetle nowego przepisu art. 25 § 2a k.k. inaczej jednak przedstawiałaby się sytuacja oskarżonego w stanie faktycznym, który rozpoznawał Sąd Apelacyjny w Gdańsku. W tej sprawie uznano przekroczenie granic obrony koniecznej oskarżonego, który odpierał zamach polegajacy na biciu i kopaniu po głowie i zaatakowaniu nożem po uprzednim wtargnięciu do mieszkania, po czym oskarżony wyrwał nóż napastnikowi i zadał mu ciosy i kontynuował je po upadnięciu napastnika na podłoge $e^{49}$. Gdyby w dacie orzekania w tej sprawie obowiazywał art. 25 § 2a k.k., oskarżony uniknąłby odpowiedzialności karnej. Podobnie rzecz ma się w odniesieniu do tezy wywiedzionej przez SN w wyroku z 27 czerwca 1986 r., w którym stwierdził on, że: „w końcowej fazie zdarzenia oskarżony miał przewage nad pokrzywdzonym, o czym świadczy doprowadzenie pokrzywdzonego do jego pokoju i rzucenie go na tapczan. Wprawdzie i na tym etapie zdarzenia pokrzywdzony atakował oskarżonego [...], jednak nie było konieczne do odparcia tego ataku takie działanie, jakie podjał oskarżony, a mianowicie śmiertelne w skutkach duszenie za szyję, i w tym należy upatrywać przekroczenia granic z punktu widzenia tego co konieczne dla odparcia ataku" ${ }^{50}$.

Odpowiedzialności karnej na gruncie nowego przepisu nie uniknąłby jednak oskarżony w sprawie rozpoznawanej przez Sąd Apelacyjny w Szczecinie, w której stwierdził on, że oskarżony odpierajacy zamach na terenie swojej posesji „miał prawo użyć pistoletu maszynowego i [...] że wybór tej broni jako środka wykonywania obrony był współmierny do niebezpieczeństwa zamachu. Natomiast [...] oskarżony nie użył owej broni z umiarem i tym samym naruszył zasadę współmierności, o której mowa w art. 25 § 2 k.k. [Z kolei - J.K.] Sąd Okręgowy zaakcentował, że wymieniony nie ograniczył się np. jedynie do

46 Uzasadnienie projektu, s. 1.

47 Ibidem, s. 2.

48 Wyrok SA w Katowicach z 21 września 2017 r., II AKa 274/17, Lex nr 2382764.

49 Wyrok SA w Gdańsku z 21 września 2016 r., II AKa 261/16, Lex nr 2157821.

${ }^{50}$ Cyt. za: R. Góral, op. cit., s. 179; wyrok SN z 27 czerwca 1986 r., IV KR 216/86, OSNPG 1987 , z. 6 , poz. 61 . 
zademonstrowania broni bądź oddania z niej tylko jednego strzału, lecz strzelił z niej czterokrotnie, i to bezpośrednio" do napastnika ${ }^{51}$, co zdaniem sądu nie stanowiło działania w ramach obrony koniecznej.

\section{WNIOSKI}

Jednoznaczna ocena dokonanej nowelizacji jest trudna do przeprowadzenia. Generalnie zgodzić się można z założeniami ustawodawcy, że w zakresie funkcjonowania kontratypu obrony koniecznej orzecznictwo prezentuje restrykcyjny pogląd. Skutkuje to stosunkowo częstym uznawaniem czynności mających na celu odparcie zamachu za przekraczające granice obrony koniecznej. W tym zakresie nowelizacja nie rozszerza granic kontratypu obrony koniecznej, jednakże poszerza brak odpowiedzialności karnej broniącego się, kiedy ten przekracza te granice w przypadku odpierania zamachu, do którego dochodzi w jego domu lub mieszkaniu. Trudno jest przy tym wymagać od broniących się znajomości skomplikowanego orzecznictwa judykatury w tym zakresie. Z drugiej jednak strony uprzywilejowanie jedynie obrony na terenie mieszkania, lokalu, domu lub przylegającego do nich ogrodzonego terenu jest nieuzasadnione. W czym bowiem obrona ataku godzacego w życie i zdrowie broniącego się w miejscu publicznym, samochodzie czy jakimkolwiek innym miejscu jest gorsza od obrony w pomieszczeniu zamkniętym? Dlatego zbytnia kazuistyczność przepisu art. $25 \S 2 \mathrm{a}$ k.k. przemawia za jego negatywna ocena. Treść tego przepisu z pewnością będzie rodzić wiele kontrowersji co do wykładni jego znamion, w czym pomóc ma niniejszy artykuł. Kierunek zmian jest jednak pozytywny, ponieważ wprowadzenie omawianej regulacji spowodować może częstsze stosowanie kontratypu obrony koniecznej oraz pozostałych podstaw wyłączenia odpowiedzialności karnej w sytuacjach rzeczywiście na to zasługujących.

mgr Jan Kluza

Uniwersytet Jagielloński

jan.kluza@student.uj.edu.pl

\section{NEW BORDERS OF DEFENCE OF NECESSITY? COMMENTS ON THE AMENDMENT TO THE PENAL CODE OF 8 DECEMBER 2017}

\section{Summary}

The article presents problems arising from the amendment to the Penal Code regarding the extension of the borders of defence of necessity. The amendment is aimed at limiting the criminal liability of the victim defending himself or herself against the assailant when the attack takes place in his or her place of residence. The article presents the reasons for the application of the introduction of this new provision, discusses it and points out the doubts that may arise in its context.

${ }^{51}$ Wyrok SA w Szczecinie z 9 lipca 2015 r., II AKa 114/15, Legalis 1372848. 